\title{
With Renewables for Energy Security
}

\author{
HAUBER György, ${ }^{1}$ HONVÁRI Patrícia ${ }^{2}$
}

\begin{abstract}
Taking into account the possible future exhaustion of fossil energy sources, the actual and near danger of climate change, the drastic increase of the greenhouse gases in the last 200 years, as well as the growing need for sustainable development, consumption and liveable environment, the increasing necessity of renewable energy sources becomes clear. Utilization of these energy sources have to acquire a bigger role in the field of energy supply, in order to enhance the energy security of Hungary, to decline the energy import dependence, to reduce the negative environmental impacts, and to recover the economy. The world's hunger for energy is growing exponentially; this is why it is crucial to establish feasibility scenarios in the next decades, which are able to meet these expectations, and to increase the safety of the energy supply.
\end{abstract}

Keywords: energy security, fossil fuels, global climate change, security of supply, renewable energy, logistic system

\section{Introduction}

In the $21^{\text {st }}$ century the excessive exploitation of the fossil fuels is continuing, endangering, on one hand the energy security of the world, and increasing the negative consequences of climate change on the other hand. At the moment, the world cannot get rid of its dependency on petroleum and natural gas. The allocation of the resources is unequal, while the economic and political systems of the energy owners are questionable from several points of view. A solution for the vulnerable situation of the consuming-importing countries is still awaited. It would take time to elaborate strategic alternatives, which decrease the dependency and answer global climate change as the most serious challenge created by the growing utilization of fossil energy sources. A solution has to be found both on global and local level. On one hand it is necessary for the European Union to have a comprehensive energy strategy that is able to reduce this dependency; on the other hand every single member state and region has to find a possible way out of this tight corner. The aim is the diversification of the sources and accessibility, the formation of appropriate safety stocks, the preparation of a scenario, and a practice in order to react quickly and efficiently in unexpected situations. Another necessary and possible alternative of the diversification is the utilization of the renewable energy sources, the application in a wider range, because in the next few decades the greenhouse gas emissions have to be cut by three-quarters in favour of sustainable development. It is important to understand, eventually, that we should not dominate the planet, but that we are a part of it, and we cannot take more from the environment than it is able to produce. This can ensure that future generations will also have the possibility for development.

1 National University of Public Service, Faculty of Law Enforcement, college teaching assistant; e-mail: hauber.gyorgy@uni-nke.hu

2 Hungarian Academy of Sciences, Centre for Economic and Regional Studies, research assistant; Széchenyi István University, Doctoral School of Regional and Economic Sciences, Ph.D. student; e-mail: honvari.patricia@rkk.hu 


\section{Geopolitical Aspects of Fossil Fuels and the Question of Import Dependency}

Energy correspondingly means political and economic power; there is an on-going, fierce struggle for its possession nowadays. This threat has effects on both a national and international level, which crucially concern the energy security both of Europe and Hungary. The world enhances the uncertainty with a lot of factors today. The different ethnic, religious, or civilization conflicts do not diminish. Wars, civil wars, dictatorships, economic crises aggravate the situation. New threats have also appeared, like terrorism or the information war. In addition to all that, the unequal distribution of the energy sources raises further problems. Social structures of the countries rich in energy sources are also leading in the direction of insecurity. It is enough to think about the armed conflict between Russia and the Ukraine, which is leading to tense relations with the EU, or about antidemocratic countries, like Azerbaijan, Turkmenistan or Kazakhstan. Similar threats can be recognized in the Middle East as well (this is the place where $65 \%$ of the world's petroleum sources are found), like the nuclear program of Iran, the Israel-Palestinian conflict, the recent terror attacks in Paris and many other outbreaks. The more energy dependent a country is, the more it is exposed to these dangers.

The main energy supply of the EU can be endangered if large-scale import is centred in the hands of only a few partners. In 2012 more than three-quarter (76.8\%) of the natural gas import of the EU-28 originated from Russia, Norway and Algeria. This way, the import sources were even more focused in these three countries than in the last two years. Shrinkage in the production of coal, lignite, petroleum, natural gas and nuclear energy caused the European Union to increasingly rely on energy imports in order to satisfy the demand. This situation has stabilized after the economic crisis; however the energy import of the EU-28 is still the equivalent of nearly 922.8 millions of tons of oil ${ }^{3}$ above export. Within the European Union the average rate of the energy dependency ${ }^{4}$ is $54 \%$, which is relatively high. There are some countries where this rate approaches or even exceeds 100\% (Malta, Ireland, Cyprus, Luxemburg), and there are some others which are in a more favourable position, like Estonia (12\%) or Romania $(21 \%)$. The import dependency of Hungary is practically equal to the Union's average with 52\%. [1] For countries with a high rate (such as Hungary) it is a top priority to dispose a long-term, computable strategy, which is able to reduce this exposure.

"Energy became the currency of political and economic power, this determines the power ranking of the nations, and this is the measure of the success and material development. This is why the access to energy is the top priority in the $21^{\text {st }}$ century. This is the leading principle of every single government's foreign policy, the none plus ultra of the global energy industry, whose success is dependent on the following: the discovery, the extraction and the selling of coal, oil and natural gas (and the end product, the electricity) in increasing quantity. However, it is easy to establish at first sight, that despite every success, our energy management is stumbling. Oil industry is one of the most vulnerable economic sectors, as it is exposed to the sudden price increases, as well as to corrupt, tyrannical and labile political systems. Though

3 TOE: tonne of oil equivalent, is a unit of energy. It gives the mass of the burned crude oil, which is essential to the production of a given quantity of energy.

4 The rate of energy dependency is a ratio, which is interpreted as the quotient of the net energy import and the gross consumption. 
natural gas is cleaner than oil, its transportation is excessively expensive, while the coal is cheap and easily accessible, however it pollutes the environment insomuch, that it causes the death of millions of people yearly." [2] These thoughts support well the power of the energy-rich countries, the vulnerability of other nations, as well as the importance of the energy security. The fights for the resources are intensifying nowadays. This danger should not be underestimated, as the "individual" interests seem to overwrite the interest of the humanity, and instead of enjoying a win-win strategy, the world can easily get involved in a lose-lose situation.

\section{The Question of Dearth}

According to the statement of the International Energy Agency, oil has a share of $40 \%$ in the energy sector, and at the moment it seems, that until the depletion of the stocks, this situation will not change significantly. Many argue, that the stocks will run out already by the middle of this century, however newer and newer oil fields are discovered and other (though less effective) resources are found. This so called non-conventional petroleum and natural gas extraction can bring new perspectives and potentially rearrange the world's energy map. These new developments have led to the fact that the peak-oil situation according to the Hubert rule did not occur in 2010. [3] However, in his book called Out of Gas, David Goodstein describes a threatening energy crisis, which is designated as the end of the oil age. This would not mean the complete depletion of the oil sources, but assumes a situation, where the oil extraction cannot keep pace with energy consumption anymore. [4] Decrease of the stocks puts the extracting and transit countries in a better position, while making the consuming-importing countries more and more vulnerable. This can lead to the rearrangement of the balance of power; otherwise it can increase the tension and create war situations.

Another significant energy source of the world is natural gas, which is responsible for $25 \%$ of energy consumption. It is more advantageous than petroleum in many ways, as the available stocks are far bigger; it is a cheaper, more convenient and cleaner energy source. Unfortunately the same problems occur with the utilization of natural gas, as $60 \%$ of the stocks are possessed by the United States, Russia and some member states of the CIS, ${ }^{5}$ in addition the supplier roads are far more vulnerable.

In order to increase the supply security, it is necessary to analyze the question of the gas storage capacity. In the beginning of the heating season the size of the reserves in the four underground gas storage areas of Hungary was 4.368 billion cubic meters. However the consumption reached 4.2 billion cubic meters, and as a consequence during the period 2.5 billion cubic meters of gas has been removed from the reserves. The inflow rate is 12.8 million cubic meters per day altogether. [5] Theoretically, it is said that our reserves would be enough for 90-100 days, however the problem is, that in the past year, by the time of the heating season, the storage level was only around $40 \%$, and even the inflow rate often lags behind the desirable rate. According to the Hungarian Natural Gas Storage Ltd. the technological level is fine and development is steady. The strategic moves in the following years have to include the following: reaching the appropriate inflow rate, as well as building further strategic gas storage and developing the existing ones.

5 Commonwealth of Independent States 
The worldwide consumption of coal is experiencing a renaissance nowadays. The resources are sufficient for another 150 years, this is one of the cheapest energy sources, and as it is almost everywhere available, it can become one of the main energy resources of the developing world. In the past decade coal consumption grew by around $70 \%$, and currently it covers $30 \%$ of the world's energy supply. The yearly growth of the coal based power generation in China alone is higher than the total renewable energy capacity of the 25 OECD countries altogether. [6] On average, one coal power plant is being installed per day worldwide. According to researchers, the coal power plants are responsible for $10 \%$ of the total carbon dioxide emissions. The health care costs due to air contamination caused by coal burning are reaching 20 billion euros according to cautious estimations, while the number of the lost workdays because of diseases related to coal burning exceeds 4 million. If in this case we ignore the external costs, the world's energy supply can easily go astray.

The danger can appear at any point in the supply chain: in the production, in the transportation, in the distribution, in the trade or in the consumption. It is not indifferent whether the resulting disturbances only affect a few elements, or having a larger scale, if they are temporary or durable, and how their impacts can be modelled. It is important to prepare for every element of danger in time, in order to avoid a global energy crisis. [3]

There is a more philosophical, however not less relevant approach to fossil energy use. Fossil fuels are labelled as income and not as capital, and according to economic rationality, which keeps in mind the maximization of income. The question is, can a "business" be feasible in the long run that absorbs its own capital because of the hunger for income. As a result of this conceptual accounting, the vanishing energy sources should be labelled as capital, and it would be obvious to minimize the present exhaustion, and to search for other, alternative production methods and lifestyles. [7]

\section{Global Climate Change}

Global climate change does not mean a risk of access to energy, however it has not foreseen and not estimated consequences. For global warming, two gases are basically responsible: carbon-dioxide and methane. The biggest " $\sin$ " of carbon-dioxide is that its atmospheric length of stay is between 20 and 150 years. This means, that the actions of the next few decades can fundamentally influence the global climate of the century end. The carbon-dioxide emissions in the middle of the last century were around 1,600 million tons, which grew fivefold until the beginning of the $21^{\text {st }}$ century. The measurement of the single gases' atmospheric concentration is the part per million (ppm). In the last 400,000 years, this concentration never exceeded $300 \mathrm{ppm}$, however since the industrial revolution it is growing exponentially, and in 2014 it repeatedly exceeded the psychological limit of $400 \mathrm{ppm}$. If the emissions continue to follow this curve, the $550 \mathrm{ppm}$ can be reached by 2035. [8]

This growing concentration is due to human activity, and not to any other reasons. However, according to the skeptics, things will get better and better, and there is no point in talking about an energy crisis. [9] In my opinion, research and examination has proved that these scientists are on the wrong track. There are some extremist theories, according to which, global climate change has already become an irreversible process, and destruction is unavoidable. Based on the Gaia-theory from James Lovelock, the Earth is one huge super organism, generating a self-regulating mechanism, it accommodates and develops, reacts to 
the occurring changes. Previously, Lovelock believed in the self-healing of the Earth, but during a visit to England in 2004, he got an insight into the newest results of climate research, and based on these results, he claims that we are beyond the point where the processes would be reversible. [10] The consequences in the light of current research are only probable. As we look further into the future, forecasts become more and more uncertain. However, it is undoubted, that we are facing a worldwide problem which can lead to a global catastrophe in extreme cases. Based on the current grade of the greenhouse emissions, by the end of the century we can reach the temperature warming 3 degrees, which is considered to be critical and will launch irreversible processes. It is unequivocal that mankind has to face the biggest worldwide market failure so far and needs to elaborate a long-term, comprehensive strategy in order to handle of the problem.

What is the grade of the carbon-dioxide concentration which is still sustainable and is not disproportionately expensive? Most scientists determine this value around 450-550 ppm, which is only feasible if the global emissions reach their maximum in the next 10-20 years, and afterwards decline by $2-3 \%$ yearly. Taking that into account, by 2050 , economic performance can be multiplied compared to today's level, then this measurement requires the drastic decrease of the emissions per GDP unit. The aim is the change-over to a lower greenhouse gas emitting economy, the establishment of climate awareness (perception), the decrease of the impact (mitigation), and effective conformation to the changed circumstances (adaptation). In order to function with these properly, the policies, the national governments, the regional economic units have to elaborate, facilitate and extort the unified market feedbacks, they have to overcome the market failures by taking into account the equality and equity.

What costs do the constraints on emission-reduction have, in addition to the installation as well as the dissemination of the new, non-coal based technologies? According to particular reports (like the $\mathrm{BAU}^{6}$ scenario) comparing the social costs of the coal against the relief and the costs of the mitigation, this would bring in most of the branches a net benefit. Based on the Stern Review, ${ }^{7} 1 \%$ of the total world GDP would be needed to change-over to the stabilization path. However, serious problems can occur from the fact that these costs are not equally distributed. At the moment, the poorest countries are mostly compromised. These nations are in a disadvantaged geographical position, as their climate is generally warmer, they are more exposed to drought, and they suffer more from the yearly change of rainfall, they are highly dependent on the agricultural sector, thus the climate change, the weather extremities affect them more sensitively. They do not have an appropriate health care system, in general they are struggling with political difficulties, the rate of corruption is high, the public administration is weak, and the GDP per capita is relatively low, which further complicates the adaptation to climate change. According to the UN High Commissioner for Refugees, if the extent of the warming does not change by 2050 , the number of climate refugees can reach a number between 250 million and 1 billion. This can lead to excessively serious social, economic and ethnic tensions, and entails a high security risk. However, these are the countries that contribute only slightly to global warming. It would be justifiable, expected and equitable, if the world's leading economic powers gave a helping hand and disencumbered these nations. [11]

6 Behavioral Analysis Unit

7 The Stern Review was published on 30th October 2006. To the request of the British Prime Minister Tony Blair, Sir Nicholas Stern, former leading economist of the World Bank made an analysis about the climate change, and the possible economic effects. 


\section{Security of Supply}

In this section, those factors are reviewed briefly which can endanger the security of supply on a national level. It is expected and likely, that on the fossil energy market serious problems can emerge in the future. ${ }^{8}$ Increase of energy-demand will enhance the powerful import dependency. At the moment, the extent of diversification is low, coupled with high and strongly fluctuating energy prices. In the case of the producing and transit countries a high security risk is observed. The threat caused by climate change is rising. Energy efficiency and the introduction of strategic green energy use are extremely slow and circumstantial.

The highest priority of Hungarian energy policy is the intensification of the supply security. According to this, balanced and durable partnership with countries and organizations rich in energy resources, a suitable energy source structure, and the diversification of the energy import and transportation routes are needed. During her visit to Hungary, German Chancellor Angela Merkell recalled, that $30 \%$ of German natural gas necessities are provided by Russia. Although Hungary is much more dependent on Russian gas, Russian energy is a vital question both to Germany as well as to other European countries. According to her, the European gas pipelines has to be connected, and an opening into Azerbaijan would be essential, in order to decrease the dependency of the Union on Russian gas. Furthermore, it is important to evolve the appropriate security stocks, supply chains and reacting protocols related to the strategic energy sources, the maintenance and development of the existing infrastructure, and the formation of logistic service centers. The decrease of the energy consumption is also pointing towards the higher security, which can be realized by the increase of energy efficiency.

According to a 2014 autumn report of the International Energy Agency, the world will utilize only one third of the available and economically recoverable energy efficiency possibilities by 2035 , if we do not change our methods. The issue of energy efficiency is underestimated everywhere, although this is the only field where economic growth can be reached without the increase of energy consumption. The American Council for an Energy Efficient Economy established in a study that the cheapest way to ensure new power generating capacities is not to build new power plants, but to increase the efficiency. With the energy efficiency programs one kilowatt-hour energy can be produced with half the costs, compared to the power plant. It is worth mentioning the research in the field of behavioral economics and choice architecture, which has reached effective results by making the energy "visible", as well as the policy measures which played a great role in awareness rising in society, making the consumers able to accept and apply the new energy sources in their narrower environment. [12] Another option of diversification is the higher utilization of green energy sources. A way out from the vulnerable import-dependency for Hungary can be the application and dissemination of renewable energy sources, both on the household level (solar panels, solar collectors, geothermal heating systems), and on the business level.

8 Hungary's long term contract with Russia on gas supply will expire this year, which can be the biggest problem of this year as regarding the tense situation. Energy needs of both the Hungarian economy as well as Hungarian households are fundamentally based on natural gas. 


\section{Hungary and the Renewable Energy Strategy}

A lot can be heard about the importance of the renewable energy sources nowadays. However, it is still questionable, what kind of role will renewable energy have in the future. Can it provide an alternative to fossil-based, excessively wasteful global energy consumption? It is a fact, that in the global world, as well as in the European Union the alternative energy sources already have an increasing role, not only in terms of utilization, but also regarding the Union directives, guidelines and policies. It is a fact, that Hungarian utilization is showing a continuous increasing tendency in the past years. And it is also a fact that more and more rural settlements are opening towards renewable energy sources, creating the base of their local economy development. Naturally, the utilization of the renewables can only work well when the national strategies, action plans and programs also confirm this need. Although the New Széchenyi Plan, the National Rural Strategy or the National Development 2030 strategic documents are all drawing up the necessary increase of the renewable rate, the concrete activities and political will is proving to be insufficient.

Hungarian energy production is fundamentally based on the nuclear power plant in Paks (38\%), while the biggest proportion of the production and import is given by natural gas and the petroleum. [13] The long-term energy strategy of Hungary does not intend to change this trend, which is confirmed by the security of supply and the lack of resources for the necessary investments; although it mentions the need to increase the share of the renewable energy sources (to $14.65 \%$ by 2020). [14] However, the present trend is not competitive, not safe and not sustainable.

The figure below shows that Hungary is in a similar position according to the energy import dependency as the Union's average, although in the last years it has exceeded it slightly. (Graph 1) This means, that in Hungary - similar to the EU - the increase of the supply security and the diversification of the energy sources is at a crucial standpoint.

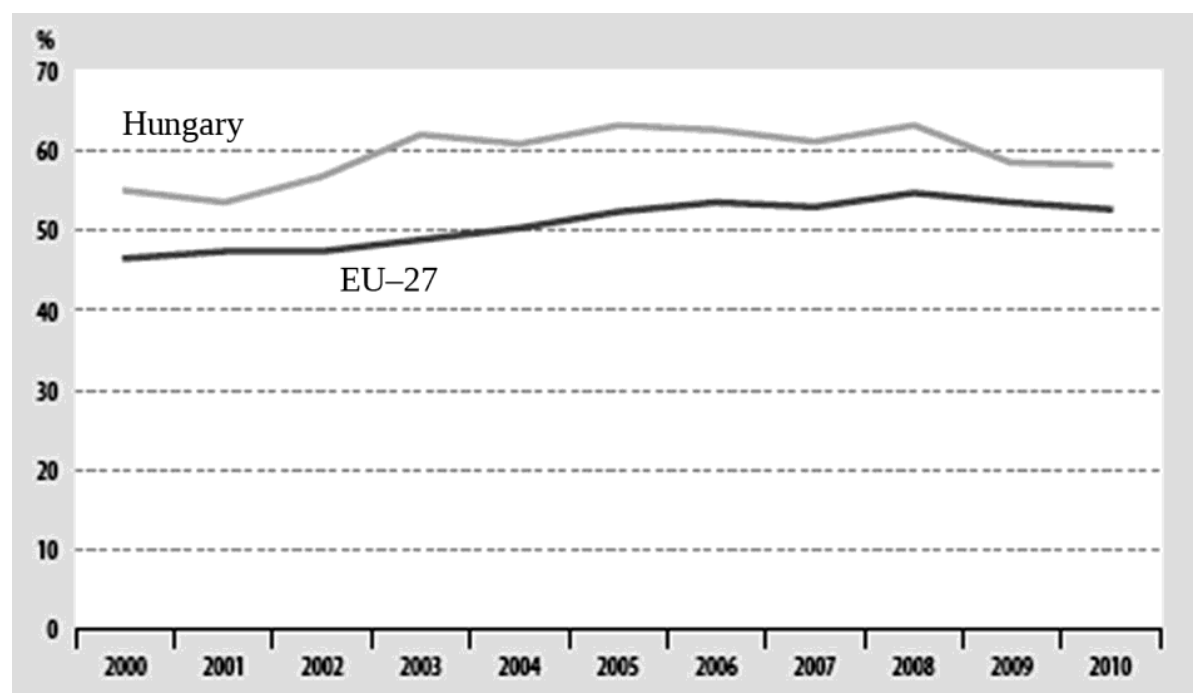

Graph 1. Energy import dependency of Hungary and the EU (\%), 2010. [15: 192] 
Within import, the volume of hydrocarbons is the highest, especially natural gas, with $80 \%$ originating from import, primarily from Russia. 37\% of the Hungarian energy consumption is based on natural gas; this is the second biggest share in the EU. In accordance with the decrease of the energy import according to the European Union directive (2009/28/ EC) Hungary has to increase the share of renewable energy sources to $13 \%$ within energy consumption. The government has set to go beyond this and set a target of $14.65 \%$ by 2020 in its National Renewable Energy Action Plan. The primary production from renewable energy sources was $9.6 \%$ in 2012, which has doubled during the last 10 years; however it is still well below the set target rate. It needs to be also mentioned that the most important renewable energy source is biomass, giving almost $80 \%$ of the renewable energy production. Although the utilization of other renewable energy sources is increasing gradually, their application is spreading very slowly. There is no significant progress in the utilization of geothermal energy. The absolute worth of wind energy and biofuels is growing rapidly, however their significance is still slight. The current utilization of solar energy is still only a fragment of the capacity, according to the potential solar radiation, its application is spreading slowly. [13]

What are those factors which can guide the renewable energy policy of Hungary, and why would it be worthwhile opening towards higher utilization? The security of supply can be mentioned in the first place, as Hungary is highly dependent on energy imports, although it is given the renewable energy potential, which could increase energy security. On the other hand, the environmental sustainability and climate protection is also a determining factor, as the utilization of renewable energy sources can decrease the application of the fossil energy sources and as a consequence the carbon-dioxide emissions as well. The environmental and nature conservation aspects are also mentioned in the National Renewable Energy Action Plan. Furthermore, an important factor is agriculture and rural development. In case of the agricultural sector, it is essential to take into consideration the aspects of sustainability. Considering rural development, it needs to be emphasized that a determinant proportion of the renewable energy can be produced in rural areas. This is why the utilization of the new energy sources should play an important role in rural development policies in the future. Development of the green economy can also be a driving factor, as the application of the renewables together with the energy efficiency programs can give a basis for a new green sector economy. [16] Last, but not least the investments in the renewable energy sources have the positive returns, that when the economy is moving in a greener direction, it also has an effect on employment also. [17] [18] However, it is not only about the increase of the absolute amount of jobs. New workplaces will be created, though there will be jobs which will be replaced, some may disappear, and there will be some professions which will be redefined. The role of education needs to be emphasized, in order to educate an appropriate workforce according to the renewed needs. [19]

As for the long-term energy strategy of Hungary, the expansion of the nuclear power plant in Paks is a foregone issue. The government has decided a long-term directive with this. The energy strategy published in 2012 also counted with this possibility, but emphasizes, that "a new nuclear investment requires significant preparatory work, and a guarantee for appropriate and safe operation according to strict regulations. Regarding the establishment of the new block of power plants detailed public information is needed, in favor of greater social acceptance." [14] The huge investment accepted without an international tender is questionable. How can the 3,000 billion Ft loan help decrease energy import dependency? It is a fact, that 
the nuclear power of Paks increases the quantity of nationally produced energy, however it also has to be seen, that the investment and credit is given by a country towards which our dependency is already huge. ${ }^{9}$ In addition, regarding the nuclear energy the question of security is always emerging. Nuclear catastrophes are not unprecedented in history, including for example the nuclear accident of Three Mile Island in the United States, Chernobyl, or the most recent Fukushima-accident.

During its communication, the government put a big emphasize on the statement, that nuclear energy is the cheapest energy source, while the most frequently mentioned negative aspect in the utilization of the renewable energy sources is the expensive change-over. Yet, what is the price of the energy? If we only take into account the net costs of the extraction, the nuclear energy - along with the fossil fuel - is indeed economical. However, if we also calculate with the costs of the investment, the long-term commitment undertaken by the loan, the rise of the security risks, the immeasurable and so far not estimated environmental damage caused by the nuclear waste, in case of the fossil fuels the great amount of greenhouse gas emissions, is nuclear and fossil energy still cheaper? The question arises: does the world have a price where the climate change, the pollution, and all the problems coming from this issue - starvation, lack of drinking water, natural disasters, extinction of animals, growing welfare gap are vastly smaller? If we consider these, which energy source would be the "cheapest"? It is important to examine the question, whether Hungary has no other chance to decrease its energy dependency, than to invest in the nuclear energy. It raises the possibility of a false long-term strategic decision. If this is the case, it is crucial to improve the strategic position of Hungary with other, mostly local and bottom-up initiatives. The national guidelines and action plans of the development policy should also confirm this need.

\section{"Think Globally, Act Locally"10}

The nuclear energy investment in Hungary is a decided question, which can determine our energy strategy in the long run. However, this does not exclude the utilization of the renewable energy potential, and making it a determinant factor in the Hungarian energy sector. It is our possibility and obligation to live with this facility and capacity; however the necessary infrastructural background needs to evolve. The system approach is important, as well as the progress along the unified and integrated strategic principles, but the actual, viable solutions has to be found on the regional and local level first. Fortunately, many effectively and economically operated local green energy supply systems are observed, which can be the basis for further adaptation. However, the establishment of the necessary supply chains cannot be forgotten. The formation of logistic supplier centers is obviously expedient where the energy production activity is in progress in a given geographical area. Accessibility is excessively important, through high quality public roads, air, water and railway routes, as well as through the info communication tools. The infrastructural facilities and possibilities of the given area need to be examined, and a development action plan has to be established. The aim is to elaborate a logistical system which satisfies sustainable development. During the production of the renewable energy intervention constraints occur, as the output of the alternative energy sources is in the most cases non-consistent. The target is the establishment of a problem

9 If we only take into account the natural gas import, Hungary's dependency towards Russia is around $80 \%$.

10 Famous thought of the Scottish urban planner, Sir Patrick Geddes. 
solving protocol, the optimized operation, distribution and appropriate utilization of the renewable energy sources through logistic systems, the elaboration of smart network-centric logistic system, which is able to bypass the constant changes of the weather, and compensate the resulting production loss towards the consumers. [20] [21] The elaboration of the local systems and the regional development has several advantages. The investment need is smaller, the delivery and storage costs can be significantly decreased, and the advantage of the local production and utilization is that the energy transportation losses can be eliminated or minimized. Additionally, it can provide a solution to excessive centralization and urbanization. Further benefits of rural development - as mentioned before - are the creation of new jobs, the increased orders at local businesses, and the resulting additional income are also mostly utilized in the given area.

\section{Conclusion}

The security of energy supply is dependent on several factors. Unfortunately, Hungary is a small, open country, and not well supplied considering the fossil energies. The energy dependency rate is high, our supply sources are limited to 3-4 countries, and the economic and political structure of these countries also means uncertainty and unpredictability. Many elements of the supply chain can hide danger, and the current war situations only create further problems and questions. In addition to these geopolitical factors, the excessive utilization of the fossil energy sources is the direct trigger of the global climate change, the consequences of which are unpredictable. However, scientists and leading politicians of the world agree that the failure of immediate interventions can cause irreversible processes. This study highlighted that there is a way out for Hungary from this non-promising situation. Possibilities given by the renewable energy sources, the potential of green energy could provide a solution already in the short run. The question is, how much energy are we able to produce, what social and economic costs will it have, and how great a degree of risk is there? How can inequitable production and opposing consumption be synchronized? [22] In this area, our energy portfolio is still unstructured, biomass is giving $80 \%$ of green energy production, while the wind-, solar and geothermal energy could also be a significant base of this sector. The most effective argument against the renewables is that their production and operation is not cost-effective at the moment, the return of investment is too long. However, if we took the social costs of the fossil energy sources also into account, the balance would move in favor of the alternative sources. In models based on renewable energy sources we cannot forget about the establishment of the supply systems, about the elaboration of a smart, network-centric logistic system, which would be able to handle the intervention constraints during operation.

It is time for thinking together and activity. Every wasted year increases the risk, and decreases the possibilities for future generations to have a better life. The success of a country having such geopolitical and natural facilities as Hungary is significantly dependent on how it can change the conventional energy sources based economic model to an alternative way. Hungary needs to establish a systemic energy strategy, which means a way out from the hardly resolvable contradictions of the present system. 


\section{References}

[1] http://ec.europa.eu/eurostat/statistics-explained/index.php/Glossary:Energy_dependency_rate (downloaded: 1705 2015)

[2] ROBERTS, P.: The End of Oil: On the Edge of a Perilous New World. Boston: Mariner Books, 2005.

[3] KATONA T. J.: Az energiabiztonság, mint rendszer. Energiagazdálkodás, 54 (2013), 6-10. [4] GOODSTEIN,

D.: Out of Gas. The End of the Age of Oil. New York City: W.W. Norton and Company, 2004.

[5] According to the data of the Hungarian Natural Gas Storage Ltd. www.magyarfoldgaztarolo.hu/hu/Ugyfelek/Adatpublikalas/TarolosiKapacitEsNapiAdat/ Lapok/default.aspx (downloaded: 1705 2015)

[6] INTERNATIONAL ENERGY AGENCY: Medium Term Coal Market Report. www.iea.org/topics/coal/ (downloaded: 1705 2105)

[7] SCHUMACHER, E. F: Small is Beautiful. Budapest: Katalizátor Kiadó, 2014.

[8] STERN, N.: The Economics of Climate Change: The Stern Review. Cambridge: Cambridge University Press, 2007. DOI: https://doi.org/10.1017/CBO9780511817434

[9] LOMBORG, B.: Cool it: the Sceptical Environmentalist's Guide to Global Warming. Budapest: Typotext Kiadó, 2008.

[10] LOVELOCK, J.: The Revenge of Gaia; Why the Earth is Fighting Back and How We Can Still Save Humanity. New York City: Basic Books, 2007.

[11] HAUBER Gy.: An Oversized World - Or the Economic Effects of Global Warming. In. Tudományos Évkönyv, Budapest: BGF, 2008, 337-345.

[12] PATAKI Gy. et al.: Nem növekedés-központú gazdaságpolitikai alternativák: A fenntartható életmód felé való átmenet szakpolitikai lehetöségei. Budapest: NFFT, 2013.

[13] KSH: Magyarország 2011. Budapest: KSH, 2012. www.ksh.hu/docs/hun/xftp/idoszaki/mo/ mo2011.pdf (downloaded: 1605 2013)

[14] NFM: Nemzeti Energiastratégia 2030. Budapest: Nemzeti Fejlesztési Minisztérium, 2012. www.kormany.hu/download/e/19/40000/Energiastrategia.pdf (downloaded: 2204 2013)

[15] KSH: A fenntartható fejlödés indikátorai Magyarországon. Budapest: KSH, 2012. www.ksh.hu/docs/hun/xftp/idoszaki/fenntartfejl/fenntartfej112.pdf (downloaded: 2105 2013) [16]

INTERNATIONAL ENERGY AGENCY: Energy Policies of IEA Countries - Hungary, 2011 Review. Paris: International Energy Agency, 2011.

[17] MAGDA R.: A megújuló energiaforrások szerepe és hatásai a hazai agrárgazdaságban. Gazdálkodás, 55 (2011), 575-588. DOI: https://doi.org/10.22004/ag.econ.119936

[18] LUKÁCS G. S.: Megújuló energia - kitörési lehetőség a szegénységből. Budapest: Szaktudás Kiadó Ház, 2010.

[19] PÁGER B.: A környezetipar szerepe a regionális gazdaság fejlesztésében. In. BARANYI B., FODOR I. (Eds.), Környezetipar, Újraiparositás és Regionalitás Magyarországon. Pécs- Debrecen: MTA KRTK Regionális Kutatások Intézete, 2012.

[20] ESTÓK S.: Megújuló energiák rendszereinek intelligens logisztikai támogatása. Hadtudományi Szemle, 71 (2014), 13-21.

[21] ESTÓK S.: Hálózatközpontú integrált interdiszciplináris logisztika. Bolyai Szemle, XVIII 3 (2009), 23-33.

[22] MACKAY, D. J. C.: Sustainable Energy - Without the Hot Air. Budapest: Typotext Kiadó, 2011. AARMS (14) $2(2015)$ 